Puyo Olga Ihorivna. Active games of preschoolers in the measurement of personal values in Ukraine. Journal of Education, Health and Sport. 2020;10(4):333-341. eISSN 2391-8306. DOI http://dx.doi.org/10.12775/JEHS.2020.10.04.036

https://apcz.umk.pl/czasopisma/index.php/JEHS/article/view/JEHS.2020.10.04.036

https://zenodo.org/deposit/4473309

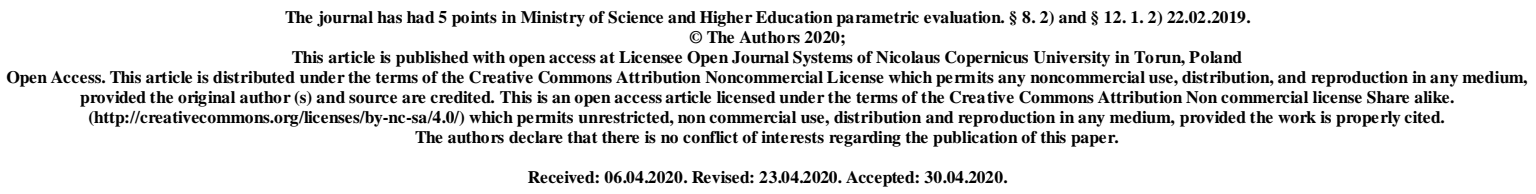

UDK 373.2.015.31:17.022.1(=161.2)]:796

\title{
ACTIVE GAMES OF PRESCHOOLERS IN THE MEASUREMENT OF PERSONAL VALUES IN UKRAINE
}

\author{
Olga Ihorivna Puyo
}

\section{Ternopil Volodymyr Hnatiuk National Pedagogical University, Ukraine}

Assistant

orcid.org/0000-0002-4910-0497

\begin{abstract}
The article is devoted to the problem of value orientations formation of personality. Scientific researches on orientations formation value at children of preschool age and process of values formation on the basis of formation and development of personal qualities are analyzed. The model of value orientations formation at children of preschool age by means of acquisition of the corresponding personal qualities is presented. The main attention is paid to the values formation of interaction, friendship and empathy by means of active games. The authors revealed the methods of formation of value orientations of preschool children and determined the features with the help of experimental data.
\end{abstract}

Key words: preschool children; active games; values; value orientations; empathy; interaction; friendship; responsibility. 


\title{
РУХЛИВІ ІГРИ ДОШКІЛЬНЯТ У ВИМІРІ ЦІННІСНИХ ОРІЕНТИРІВ ОСОБИСТОСТІ В УКРАЇНI
}

\author{
Ольга Ігорівна Пуйо
}

\author{
Асистент Тернопільського національного \\ педагогічного університету імені В. Гнатюка, Україна \\ orcid.org/0000-0002-4910-0497
}

Стаття присвячена проблемі формування ціннісних орієнтирів особистості. Проаналізовано наукові дослідження щодо формування ціннісних орієнтирів у дітей дошкільного віку та процесу становлення цінностей на основі формування та розвитку особистісних якостей. Представлено модель формування ціннісних орієнтирів у дітей передшкільного віку за допомогою набуття відповідних особистісних якостей. Основна увага приділена формуванню цінностей взаємодії, дружби, співпереживання засобами рухливих ігор. Автори розкрили шляхи формування ціннісних орієнтацій дітей старшого дошкільного віку та визначили особливості за допомогою даних експериментального дослідження.

Ключові слова: діти дошкільного віку; рухливі ігри; цінності; ціннісні оріснтири; співпереживання; взаємодія; дружба; відповідальність.

Formulation of the problem. In our time, the problem of personal values is more critical than ever in society. Without a doubt, one of the priority values is human health. In modern conditions of development of society the state of health of preschool children constantly getting worse. One of the reasons for this is a sedentary lifestyle, the lack of active games in the lives of children.

Active games are a natural means of ensuring the successful development of the child. Traditionally, under active games we understand the game, which is aimed at the development of physical qualities of a child. However, the developmental potential of active games is much wider, and the displacement of the game from the lives of modern children has negative consequences not only for health [1]. After all, in the active games of children, not only physical and volitional, but also spiritual qualities are tempered - the values of friendship, responsibility, interaction, empathy arise and are fixed. In the fight for the health of children, adults do not always focus their attention and their wards on the moral and ethical 
component of each game. Therefore, the question of value orientations formation of preschool children with the help of active one is a priority direction of the study.

Analysis of recent research and publications. Value orientations of preschool children as an important criterion of moral orientation of the child's personality were investigated by V. Zaporozhets, A. Makarenko, T. Ponimanska, V. Sukhomlinsky. At the present stage, the problem of value orientations formation of preschool aged children is investigated by H. Belenka, S. Ladivir, A. Polova, A. Tokareva, T. Titarenko, T. Pirozhenko.

The purpose of the article is to analyze formation of values of senior preschoolers in the course of active games in Ukraine.

Research results. According to the results of the study, among all the value orientations that took the first steps in the hierarchy of values of children, only "friendship" is known to them, important and able to influence behavior. Thus, according to the study of T. Pirozhenko, senior preschoolers understand the concept of "friendship" as the presence of friends when "they are friends: play together, have fun, share everything, never quarrel and help each other" [5]. This understanding of the value of "friendship" indicates the importance for senior preschoolers communication on the principles of effective interaction, mutual understanding and support. T. Pirozhenko believes that confidence, commitment, perseverance are values of the individual. Despite this, before adults who are engaged in the education of preschoolers, the task of providing conditions for children to gain experience of overcoming obstacles by their own efforts.

Let us not agree with this vision of values, because confidence, perseverance, commitment, as well as responsibility and tolerance are personal qualities, moreover they are the basic qualities of personality, on the basis of which the character of a person is formed. We agree with the position of scientists of the Institute of psychology G. S. Kostiuk NAPS of Ukraine in relation to the understanding of such qualities as perseverance, dedication, curiosity, responsibility, empathy, creativity as the basic plan of formation of valuable orientations of the person [6]. However, we consider them as qualities manifested as a result of the formation of values of interaction, empathy and friendship (Annex 1).

Meaningful uncertainty of elder preschoolers values of empathy negatively affects the development of empathy as the basis of mutual understanding. Lack of empathy impairs the interpersonal interaction of preschoolers and can be a cause of indifference in relationships. Confidence, empathy are not popular with preschoolers. A low level of emotional intelligence leads to a lack of personal attitude in the interpretation of the experience of communication and activity, a decrease in the regulatory role of values in the life of a preschooler. In the 
emotional sphere of modern children, contradictions related to the nature of interaction between the inner world of the child and the social environment are revealed [6]. They are reflected in the attitudes of preschoolers during different activities. This trend threatens in the future problems in teamwork and the formation of the ability to cooperate and to come to an agreement.

Annex 1

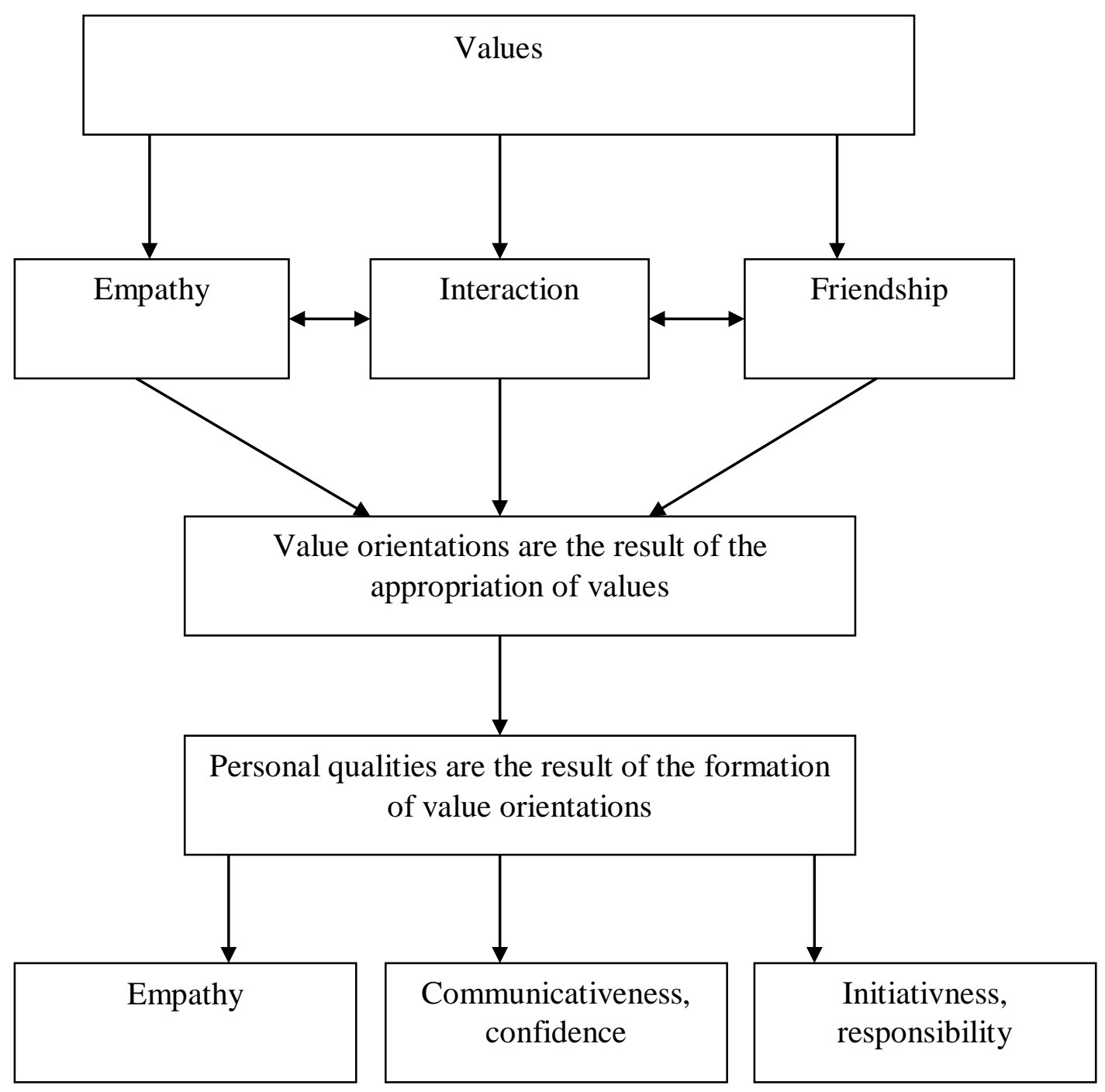

T. Pirozhenko and K. Karasiova prove that the assignment of instrumental values occurs in the following way: active $\rightarrow$ emotional $\rightarrow$ cognitive component. Active one involves partnership with peers (to establish, support, enjoy, guide), emotional one - the definition of evaluation and the degree of significance for the child (the formation of attitudes to the manifestation of socially significant ideal in their own behavior), cognitive one - filling of the images content of values, the formation of ideas, concepts about them [6]. According to the results of long-term observation of children's active games, we found that the values of 
communication are acquired by senior preschoolers through the passage of a slightly different path: emotional - cognitive - active component. This is due to the fact that attempts to show empathy are not qualitatively significant until the child begins to distinguish between his own emotions, the emotions of peers, learns how to show them and will continue to apply in action.

Thus, the game contributes to the formation of value orientations of preschool children through the implementation of emotional cognitive - active component of value orientations.

We agree with the opinion of D. Goleman (researcher of the art of social interaction) in relation to the fact that the coherence of movements during a conversation is an indicator of proximity [3]. He emphasizes that movement is the means that can form interaction and emotional harmony during different activities. This opinion is the main theoretical basis of our research.

In Wagner's study of educational processes, the seven survival skills are: critical thinking and problem solving, effective teamwork and the ability to be an example to others, flexibility and the ability to adapt, initiative and entrepreneurial spirit, effective communication, search and analysis of information, curiosity and imagination. Of course, such skills can be formed by different means. However, for the preschooler, T. Wagner identified those that most excite the interest of the child: active games, crafts, drawing, singing, inventing questions [2]. The data of theoretical research require verification by means of practical research.

Formation of values of senior preschoolers in the course of active games: a practical study. We did the research through observations, clarifying conversations, a survey. Organized games with children of the senior preschool group, game exercises for the purpose of definition of existence of valuable orientations at children and their manifestations in game situations. 122 children of senior preschool age took part in the experiment: 60 children of the control group (CG) and 62 children of the experimental group (EG). The observation was long and included watching the children's actions and analyzing their behavior in 30 active games.

One of the values we explored was empathy. This very value that is decisive in the list of soft skills of the XXI century. During the active game "Cat and mouse" the girl Olenka fell and then sat on a bench. Her classmate Katia ran up to her, sympathized and persuaded her to continue the game. But when Olenka refused, complaining on pain in knee, her friend also did not returned to classmates, staying with Olenka. Kate on the question of the teacher: "Why did you decide to do so?" Answered : "Because friends should be pitied." This situational 
manifestation of empathy indicates that children are able to show it during active play, of course not for everyone, but when their empathy requires his or her friend.

In previous publications [1] we noted that we agree with T. Pirozhenko's opinion that the last place in the hierarchy of children's values is occupied by the terminal value "empathy". Children reveal the content of this concept as follows "when a person experiences; feels something; when the baby cries, the mother experiences". Despite the fact that "empathy" was determined by one of the least known and emotionally attractive values in most children, in the behavior of a small number of preschoolers, this value performs its regulatory action. As a result of rapid diagnosis, the value of empathy is determined by elder preschoolers as follows: "Empathy - when the wind is strong and everyone is holding hands". This definition coincides with the understanding of the qualities of responsibility and empathy. The values of empathy, interaction and friendship are realized in relation of a person to person and relate to the values of communication. They are manifested in active forms of interaction with the environment, as well as in game situations [5].

The term "motive mimicry" conveys the technical meaning of the word empathy, in which it was first used in the 1920s by the American psychologist E. Titchener. It differs from the word of Greek origin "empathy". The term theorists such parts of philosophy as aesthetics, used to denote a person's ability to perceive the subjective experience of another human, since empathy originates from the physical simulation in its action and subsequently generates in man, which resemble those feelings [3]. The empathic attitude of children to each other is the result of the educational influence of adults on them, which use a variety of means for this purpose.

Describing the situation of compassion in kindergarten, D. Goalman reveals the essence of the formation of interpersonal intelligence (that is, empathy) in a preschooler, as the ability to recognize what friends feel, easily and quickly establish communication with them, the ability to show mutual understanding. Qualities of empathy, responsibility, confidence, tolerance, initiative, communication are very important in adult life, but are formed in preschool age. These qualities are manifested as a result of the formation of value orientations.

G. Gardner, one of the components of interpersonal intelligence defined personal communication - the ability to empathize and establish a connection that helps to start interacting with others, to recognize people's feelings and properly respond to them. Having such skills, the child becomes a good "team player", a good friend [3]. 
The study of personal qualities of preschoolers, which is evidence of their value orientations. Another important quality that we investigated in preschool children was responsibility, as we consider it a manifestation of the value of friendship [4].

So, playing the active game "Sparrows and cars" most of the children of the senior group adhered to the rules and responded to the commands of the leader in time. However, some children did not want to return to the house on the signal and broke the rules of the game. During the summing up, the teacher asked the breakers why they did not follow the rules. They explained that it was more fun to play. Based on the observations and responses of children, we came to the conclusion that the ability to comply with the rules of an active play is important in the formation of children' responsibility of senior preschool age. Unwillingness to comply with the rules of the game indicates a low level of responsibility.

Over the course of long-term observation of children's games, we have seen that caregivers have repeatedly encouraged inactive children to play. Verbal encouragement was not effective. However, the instructions to perform a new, special role of the "Judge" during the "Fun football", the "Timer" during the game The third is extra" worked as an encouragement and children joined the games. This shows that trust, the assignment of a special mission helps to encourage children to participate in active play, as well as contributes to the development of responsibility, initiative, confidence and, accordingly, the formation of the value of interaction.

Pedagogical observation allowed us to determine that the manifestation of empathy, responsibility and confidence can be traced during outdoor games, in which there is an element of danger in the plot (for example, "The Hunter and the hares", "Geese-geese"). In such games, according to the rules, children hold hands, running away to save a friend. This element/rule of the game is extremely important for the development of friendly feelings in children, as well as for the feeling of self-confidence. During the game "Cross the river", when children move on the bridge (rope, gymnastic ladder), they are more confident and less worried when they walk hand in hand. In the active game with elements of didactics "Jump and name", if the child performs the task on his own basically he performs only part of the task: either jumps or calls part of the cards. If a friend or caregiver holds a child's hand the child jumps and calls all the cards. Also in the Ukrainian folk games: "Fence", "Crossing the river" children during the game task take hands. This gives to senior preschoolers a sense of emotional comfort, empathy with the process of joint activity and the result. Also in relays with the condition of joint transfer of the object (ball, hoop and other items), working in pairs, preschoolers learn to cooperate, empathize and be responsible for the task. 
So, the second hand is a manifestation of empathy, game interaction during the game and gives confidence that the child of senior preschool age is able to cope even with very difficult tasks of the game, thanks to the values of interaction, empathy and friendship.

Reflection during outdoor games. Observation of the organization of relays of children of the senior group, gave the chance to see that they willingly responded to the offer of the teacher, actively participated in games. According to the results of the game, one of the teams won, but the teacher did not take this into account and announced to everyone that friendship won. The children reacted very emotionally to this summing up. Those who played better shouted that it was not fair and they would no longer participate in the games. The teacher to the question: "Why did you declare that friendship has won?" answered that otherwise children who lost could both cry, and be offended.

In our opinion, the results of the game are extremely important in terms of motivating children to play next time. If everyone wins the friendship, then the children of senior preschool age will lose interest in games with competitive effect. In order for children not to have disappointments, it is necessary to prepare them before the game that someone will be defeated and someone the winner and this is temporary. Also effective in terms of the outcome of the results of the game, in order to educate children of moral value orientations, the reflection is.

\section{Conclusions and directions for further research}

Thus, based on the analysis of scientific research and results of long-term observation of preschool-aged children during active games. We claim that the values of friendship, interaction, empathy are successfully formed through the active games according to the proposed model. Further scientific research requires a formative experiment.

\section{References}

1. Bielenka H., Puyo O. Empathy formation of senior preschool aged children in the process of active games. Modern World tendencies in the development of science. 2019. London. Vol.2. 16-25.

2. Vagner T., Dintersmit T. Mystetstvo navchaty. Yak pidhotuvaty dytynu do realnoho zhyttia. K. 2017. 312 s.

3. Goulman D. Emotsiinyi intelekt. Kh. 2018. $512 \mathrm{~s}$.

4. Puio O. Do problemy formuvannia tsinnisnykh oriientatsii ditei starshoho doshkilnoho viku zasobamy rukhlyvoi hry v zakladakh doshkilnoi osvity. Narodna osvita. 2019. Vyp. 2. URL: http://nbuv.gov.ua/UJRN/NarOsv_2019_2_10 
5. Pirozhenko T. Tsinnisni oriientatsii ditei starshoho doshkilnoho viku $\mathrm{v}$ sohodennykh realiiakh zhyttia. Aktualni problemy psykholohii: zbirnyk naukovykh prats Instytutu psykholohii imeni H.S. Kostiuka NAPN Ukrainy. 2014. Vyp. 4 (1). S. 172-186. URL:

http://lib.iitta.gov.ua/8535/1/Сучасні\%20діти\%20\%20відображення\%20\%20цінностей\%20\%20дорослого\%20\%20світу.pdf

6. Pirozhenko T., Karasova K., Soloviova L. Tsinnisni oriientatsii dytyny: tendentsii rozvytku. 2013.

URL:

http://lib.iitta.gov.ua/4631/1/Ціннісні_оріснтації тенд._розвитку.pdf 